\title{
Japanese Cartoons, Virtual Child Pornography, Academic Libraries, and the Law
}

\section{Glenn Masuchika}

Glenn Masuchika (gnm1@psu.edu)

is information literacy librarian at

Pennsylvania State University Libraries,

University Park, Pennsylvania.

Reference \& User Services Quarterly, vol. 54, no. 4, pp. 54-60

(c) 2015 American Library Association. All rights reserved.

Permission granted to reproduce for nonprofit, educational use.
Many academic libraries are adding comics and cartoon in print form to their collections. Japanese comics, called "manga," are a large part of this collecting. However, in some of these items, there are drawn images of people seemingly under eighteen years of age engaged in highly graphic, uncensored, sex acts. The purpose of this paper is to discuss whether collecting such materials may violate anti-obscenity laws of the United States and expose the collection developer and the library to criminal liabilities. It also suggests that these concerns can lead librarians to self-censorship in their collection development duties.

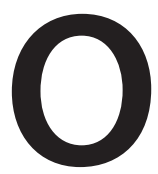

n March 10, 2006, Dwight Whorley was sentenced to twenty years in federal prison on child pornography charges. ${ }^{1}$ Whorley, a man with a history of receiving and sending child pornography via email, and who has previously served time in federal prisons for those offences, was convicted among other charges of using a public computer at a Virginia Employment Commission office on March 30, 2004, to receive twenty Japanese cartoons that showed seemingly minor (younger than eighteen) females engaged in sexual intercourse with males seeming older than eighteen. This part of his conviction and his sentencing was based on his violation of the 2003 PROTECT (Prosecutorial Remedies and Other Tools to End the Exploitation of Children Today) Act. His appeal to reverse his conviction was denied by the courts. ${ }^{2}$

In May of 2006, the US Immigration and Customs Enforcement (ICE) confiscated a package mailed from Japan to Christopher Handley, a comic books collector in Glenwood, Iowa. The package contained Japanese comic books that had cartoon visualizations of seemingly minor females engaged in sex with older males and animals. The US Postal Inspection Services served a search warrant on Handley and subsequently found and seized from his home other drawings of children engaged in acts that they concluded was sexual abuse. Handley was convicted, as Dwight Whorley was, on violations of the 2003 PROTECT Act, and his appeal for dismissal was denied. ${ }^{3}$ On February 13, 2010, Christopher Handley, who had no criminal history, was formally sentenced to six months in prison for importing and possessing seven Japanese comic books depicting cartoon children having sex. The books Handley bought were available through the Japanese Amazon website. ${ }^{4}$

Graphic novels, comic books, and cartoons have become an extremely 
popular area of collection development in both academic libraries and public libraries. ${ }^{5}$ As more artists embrace this visual form of artistic representation to express the major and minor themes of the human experiences, librarians are responding to this burgeoning medium of information transmission by actively adding these materials to library collections. Yet with new media come new areas of concern. By definition, child pornography-for our argument, the visual exploitation of children in sexual situations-is not a legitimate area for collection. The production of child pornography that uses actual children must be prevented, and libraries, through their purchasing power and their wide outreach to the public, can aid in the halt of further distribution of this pernicious material. However, themes of the human condition often include the unsavory, vicious, nasty, and cruel, and comics and cartoons, with their subversive, rebellious, "underground" history, are a good media for the expression of these themes. It is no surprise that examples of highly graphic nature, both violence and sexual, can be found in the pages of graphic novels. And as the comics and cartoons make their way into the collections of libraries, it is also not surprising that sexualized images, produced without any human beings participating, sometimes featuring children, are also found in libraries.

The purpose of this article is to investigate whether academic librarians, in their legitimate performance of their duties as collection developers, have any immunity from criminal prosecution, especially from any violation of the 2003 PROTECT Act. It is not the purpose of this article to argue whether this law is unethical, unconstitutional, illogical, or potentially illegal in its overreach. This article is instead concerned that little in the library literature covers criminal violations by librarians. Because of the indictments and convictions of Dwight Whorley and Christopher Handley, and the inherent sensationalism of anything mentioned as child pornography, it is not difficult to imagine that librarians could be accused for purchasing and possessing child pornography (in our case, Japanese cartoons).

\section{"PORNOGRAPHY" VS. "OBSCENITY": A LEGAL DIFFERENCE}

For the legal scholar, the words "pornography" and "obscenity" have different meanings and different legal standings. Legal dictionaries define "pornography" as materials, such as books, magazines, photographs and pictures, movies and films, etc., depicting sexual or erotic activities that are purposely meant to arouse sexual excitement or pander to one's prurient interests, ${ }^{6}$ and "obscenity" as materials that are morally abhorrent by appealing to prurient interests, and lack serious literary, artistic, political, or scientific value. ${ }^{7}$ Both definitions include a sexual aspect, with the definition of "obscenity" expanded to include social values. Besides these semantic similarities and differences, the major difference between these two words is the protection they receive under the First Amendment of the Constitution of the United States. ${ }^{8}$ The Supreme Court of the United States held that materials considered pornographic, including their creation, sales, advertisement, and distribution, constitute speech protected by the First Amendment and cannot be prosecuted as a crime. ${ }^{9}$ Obscene materials (or obscenity in general) is not protected speech and can be severely regulated by the government or even banned as a violation of criminal law. ${ }^{10}$ The purveyors of obscene materials, by creating, selling, advertising, distributing, and otherwise making them available, can suffer fines and imprisonment.

For the purposes of this paper, we will consider "pornography" a necessary component to the definition of "obscenity" because, etymologically, not everything that is obscene has a sexual component to it, ${ }^{11}$ yet both have different legal consequences. The next two sections will investigate how these definitions of what is pornographic and what is obscene grew out of both legislative law and case law, and how the present definitions and criminal liabilities of child pornography were developed.

\section{ANTI-OBSCENITY LAWS: FROM COMSTOCK TO MILLER}

Politicians in nineteenth-century America and England began the long campaign against the proliferation of obscene materials. In the United States, Anthony Comstock lobbied for and successfully passed federal laws prohibiting the sale and distribution of sexual materials, both visual and written. This federal law was called the Comstock Act. ${ }^{12}$ In England, the case of Regina vs. Hicklin tested the definition of obscenity established by the Obscene Publication Act of $1857 .{ }^{13}$ The court decided that all materials that corrupt minds with immoral thoughts are obscene and can be destroyed. Any work, even if it had literary, artistic, political, or scientific value was banned if it brought moral detriment to the weak-minded. This was later referred to as the "Hicklin" test. ${ }^{14}$

In the United States, the concept of obscenity was slowly coalescing. In 1893, Lew Rosen was indicted in New York for using the US Post Office to mail materials considered obscene. Rosen appealed to the Supreme Court and lost his case ${ }^{15}$ however, the Court began defining that "the test of obscenity is whether the tendency of the matter is to deprave and corrupt the morals of those whose minds are open to such influence and into whose hands a publication of this sort may fall." ${ }^{\prime 6}$

The matter of what is and what is not obscene stumbled through the state and federal courts for decades, and judges often could not agree on the requirements for determination. That changed in 1957 in the case of Roth $v$. United States when the Supreme Court narrowed the definition of what is obscene. ${ }^{17}$ The Court rejected the Hicklin test that work could have literary, artistic, political, or scientific worth and still be considered obscene, ${ }^{18}$ and defined obscenity as work where "to the average person, applying contemporary community 


\section{FEATURE}

standards, the dominant theme of the material as a whole appeals to prurient interests,"19 and where the work is "utterly without redeeming social importance." ${ }^{20}$ It also reestablished that obscenity was not protected by the First Amendment. ${ }^{21}$

So now, the various law-enforcement agencies and the courts had some guidance to measure the "obsceneness" of materials; however, these guidelines clearly were not complete and well defined-even the Supreme Court justices still had trouble with definitions. The challenge of applying these standards was shown in the case of Jacobellis vs. Ohio, ${ }^{22}$ an appeal by Nico Jacobellis, a manager of a movie theater in Cleveland Heights, Ohio, who was convicted for showing the French film Les Amants (The Lovers). The Supreme Court reversed the conviction, saying the film was not obscene; ${ }^{23}$ however, the court could not uniformly agree on why the film was not obscene. The confusion over a definition of obscenity was best presented by Associate Justice Potter Stewart's opinion, "I shall not today attempt further to define the kinds of material I understand to be embraced within that shorthand description; and perhaps I could never succeed in intelligibly doing so. But I know it when I see it, and the motion picture involved in this case is not that." ${ }^{24}$

A later case further refined the definition of obscenity. In 1971, Marvin Miller owned a mail-order business offering pornographic materials to adult buyers. Miller was found guilty of violating a California law making the mailing of such materials illegal. In appeal to the Supreme Court, ${ }^{25}$ the court found that for work to be considered obscene, it had to meet these basic guidelines: (1) whether the average person, applying contemporary community standards, would find that the work, taken as a whole, appeals to the prurient interest; (2) whether the work depicts or describes, in a patently offensive way, sexual conduct specifically defined by the applicable state law; and (3) whether the work, taken as a whole, lacks serious literary, artistic, political, or scientific value. ${ }^{26}$ These three guidelines would set the Miller test and be used to define what is obscene and thus not protected speech.

\section{VIRTUAL CHILD PORNOGRAPHY: FROM FERBER TO THE PROTECT ACT OF 2003}

The area of child pornography was separated into its own subarea of concern with the 1982 Ferber case. ${ }^{27}$ Paul Ferber, owner of an adult bookstore, sold two films of boys performing sexual acts to an undercover police officer, and Ferber was arrested for violating the obscenity laws of the State of New York. His appeal was based on his First Amendment rights of free speech and that his conviction did not meet the Miller standards of what was obscene. The case was eventually appealed to the Supreme Court, and his conviction was upheld. The Court decided that child pornography, because of its pernicious and damaging nature to the children involved in its production and the psychological damage it does to the child knowing the pornography is being distributed, can be banned even if it did not meet the Miller definitions of obscenity. The opinion reads,

The test for child pornography is separate from the obscenity standard enunciated in Miller, but may be compared to it for the purpose of clarity. The Miller formation is adjusted in the following respects: A trier of fact need not find that the material appeals to the prurient interest of the average person; it is not required that sexual conduct portrayed be done so in a patently offensive manner; and the material at issue need not be considered as a whole. ${ }^{28}$

In 1996, the US Congress, in an attempt to codify the federal laws and influence the laws of the states, passed the Child Pornography Prevention Act (CPPA). The CPPA gave the government wide powers to restrict child pornography in its creation, ownership, sale, and distribution. A major reason for the creation of the CPPA was to stop the new technologies of computer imaging and distribution via the Internet. The CPPA defined "child pornography" as

any visual depiction, including any photograph, film, video, picture, or computer or computer-generated image of picture, whether made or produced by electronic, mechanical or other means, of sexually explicit conduct where... such visual depiction is, or appears to be [emphasis added], of a minor engaging in sexually explicit conduct. ${ }^{29}$

The CPPA forbids "such visual depiction is advertised, promoted, presented, described, or distributed in such a matter that conveys the impression [emphasis added] that the material is or contains a visual depiction of a minor engaging in sexually explicit conduct." ${ }^{30}$ Implicit in these definitions is that child pornography includes anything that "appears" to be real and need not be "real."

Following the passing of the CPPA, people in the adult entertainment industry sued the federal government on the grounds that the CPPA's words, such as "appears to be" and "conveys the impression," were too vague and overreaching into areas of protected speech. The case was eventually brought to the Supreme Court, ${ }^{31}$ and the CPPA was found unconstitutional and overturned becaue of the vagueness of the above sections. It was also found that the CPPA was not in compliance with Miller, having no prescribed definitions of what obscenity is.

In response to the overturning of the CPPA, the US Congress passed into law the PROTECT Act of 2003. The Act included a line that only obscene material can be bannedthus reinstating the Miller test-described the various sexual acts that can be used by a court to establish if a work is obscene, and reiterated that a work must lack serious literary, artistic, political, or scientific merit. ${ }^{32}$ The Act also makes explicit two conditions. First, that child pornography can be "a visual depiction of any kind, including a drawing, 
cartoon, sculpture, or painting." ${ }^{33}$ Second, that "it is not a required element of any offense under this section that the minor depicted actually exists." 34

Both Dwight Whorley and Christopher S. Handley were convicted under this section of the law, and it is this section that potentially makes collecting Japanese manga problematic for librarians.

\section{JAPANESE CARTOONS: CULTURAL DIFFERENCES?}

It was earlier stated that the breadth of graphically presented materials being collected by libraries is growing year by year and shows no signs of stopping. A popular subset of this genre are Japanese comic books called "manga." 35 Besides their popularity, manga are also valuable resources for scholars in academic fields such as graphic arts, storytelling, and digital game design as well as in Asian Studies, world literature, linguistics and semiotics, aesthetics, and other areas in the humanities and social sciences. To deprive students and scholars access to this growing field of narrative art would be difficult to support.

However, Japanese manga have an unsavory reputation of containing seemingly pornographic, or even obscene, material. ${ }^{36}$ News reporters have written about the proliferation of manga that could be classified as child pornography. ${ }^{37}$ There is no doubting that there are highly sexualized manga being produced and distributed in Japan. There is also a tradition of comics drawn in the manga style by amateur manga artists that can be highly sexualized, called doujinshi. ${ }^{38}$ Yet to bundle all comics of a particular style together on the basis of their visual means of expression would be to include comics such as Peanuts and Family Circle with the violent cartoons found in uncensored websites, which is neither logical nor appropriate.

This perception of manga being pornographic is partly derived by western eyes looking at the culture of Japan. The artwork found in manga is standardized: characters have pentagon-shaped heads topped usually with large jagged hair, very large eyes, an insignificant nose, and a mouth that widely expand and contracts. The large eyes often give the females an adolescent look that the Japanese call "Kawa-ii" or "cuteness." 39 This "cuteness" gives the females an appearance of being younger than eighteen, whether they are in the narrative. Unless someone is fluent in reading the Japanese language, one cannot be sure of the female character's chronological age as stated by the author in the work. Second, there is more of an acceptance of nudity in Japanese culture than in western cultures, and this is reflected in the manga. It is not unusual to find in manga or in Japanese animated cartoons, called "anime," ${ }^{40}$ nude males or females, usually in comic scenes. A very common scene in both anime and manga are bare-breasted females enjoying a leisurely soak in one of Japan's hot spring resorts, called an onsen. Nudity of little children with adults is also not unusual. The Hayao Miyazaki's 1988 movie My Neighbor Totoro-a fanciful animated film about two girls who meet a mythical huge, part-rabbit, part-badger, benevolent creature in the countryside of Japan-contains a scene where the father innocently baths in a wooden tub full of water, or furo in Japanese, with his two daughters, ages approximately nine and five. Family or communal bathing was practiced in the 1950s, when the movie takes place, and communal bathing occurs today. However, the adolescent appearances of characters and occasions of nudity, sometimes adults with children as the scene described above, invite initial accusations of child pornography.

\section{CIVIL LIABILITIES FOR THE LIBRARIAN?}

In law, the offences against a person or establishment usually take one of two types: civil or criminal. In the subset of liability law, there are also two types: civil and criminal. The civil legal system is responsible for persons who are harmed by another seeking redress or compensation for injury. The criminal legal system is responsible for all liability cases where the harm is to the state. In the civil legal system, a person is found liable and must pay restitution. In the criminal legal system, a person found liable is declared guilty of the crime. ${ }^{41}$

In the performance of any job, potential liabilities constantly occur, especially in a profession that involves the passing of information from one person to another. The librarian is at the epicenter of this potential storm. The patron of the library expects the information received from the "information professional" to be accurate and true; however, this is clearly an impossibility as no librarian has the capacity to know all things or whether all sources (e.g., books, journal articles, facts from databases, etc.) are up-to-date, accurate, and reliable. To remedy liability of librarians, the courts of the United States, both state and federal, have decided that librarians are "public officer[s] or public officials" and have immunity from certain liabilities in the performance of their tasks to meet the needs of the public just as other public officers have. ${ }^{42}$ Two cases are examples of this reasoning. On October 20, 1988, Renee Kimps, a student at the University of Wisconsin-Stevens Point, was injured when a pole supporting a volleyball net fell on her. She sued Leonard M. Hill, a physical education professor for negligence. The Court of Appeals of the State of Wisconsin decided that Hill was entitled to public officer immunity and not liable for the injury. ${ }^{43}$ The second case involved Arnold Via, the director of the Virginia Chapter of American Atheists. In 1981, he offered gratis a copy of their organization's magazine The American Atheist to Howard M. Smith, City Librarian of the City of Richmond, Virginia. The offer was refused. Arnold Via sued the City of Richmond that the refusal of his magazine violated his rights under the First Amendment restricting a fee exercise of religion. The District Court of Virginia found that public officials, as such as librarians of the Richmond 


\section{FEATURE}

Public Library, are entitled to be protected from harassment by lawsuits. ${ }^{44}$

As public officers or public officials, librarians are covered by different forms of immunity, however the most common is discretionary immunity. Discretionary immunity protects a librarian against civil lawsuits if in the course of their duty and on the basis of their knowledge of their profession, they inadvertently cause harm or damage to another. ${ }^{45}$ A librarian, as a professional, exercises discretion, offering to the public what is believed to be the information they need. An example could be if a patron comes to the library for information and the librarian, using his or her best skills and knowledge, offers inaccurate information, believing it to be accurate, to meet the patron's needs. If the information causes harm or damage to the patron who acts on it, the patron can file a suit against the librarian and the library, but both are protected by discretionary immunity. However, this discussion of the limitation of civil liabilities of the librarian should not cause undue comfort. Despite the fact that the tendency in law is to protect the librarian from lawsuits, complete immunity is a myth. Healey says, "Librarians liability for actions at the reference desk does appear to be a myth. That is, it appears to be a belief given uncritical acceptance by members of the library profession." ${ }^{\text {"6 }}$

During the spring of 2014, case laws and articles concerning a librarian's immunity from charges of purchasing or owning virtual child pornography were searched for in the legal databases LexisNexis Academic and LoisLawConnect, repositories of both state and federal case law, and the library and information databases Library and Information Studies Abstracts; Library, Information Sciences, and Technology Abstracts; and Library Literature and Information Sciences. There were no retrievals. If civil cases have been filed or if librarians and libraries have been convicted, the cases are local ones that have not been reported in the various court publications and none of the cases were appealed.

\section{CRIMINAL LIABILITIES OF THE LIBRARIAN: THREE POSSIBLE DEFENSES}

Cases exist where individuals who have created, advertised, sold, and distributed obscene materials, have been convicted of violating local, municipal, and state laws, yet there are no cases reported in the law literature of a librarian being arrested and convicted on obscenity charges in the performance of their stated duties in collection development. With no reported cases, there are no precedents from which to deduce if librarians have immunity from criminal prosecution, similar to discretionary liability immunity, especially from child obscenity cases. At the same time, a search through the literature did not locate any legislative actions that granted librarians immunity from criminal violations. Thus it would appear that there is neither immunity legislation nor judicial precedent to help us in our study.
There is no reason for librarians to believe there is any immunity from purchasing or owning virtual child pornography. Like civil actions, all is needed is a complaint, an investigation, and if the facts prove, an arrest. However, one can contemplate a few arguments against a librarian being charged with collecting virtual child pornography that could possibly be considered obscene. Although each state has its own legislative law and case law pertaining to the criminal liabilities of child pornography, this part of the paper will concentrate on the federal PROTECT Act with knowledge that it has influence over local and state law. An argument against any action against a librarian is found in the wording of the Miller test. After the CPPA of 1996 was found unconstitutional, the PROTECT Act of 2003 states that for child pornography to be considered obscene and without the protection of the First Amendment, it has to meet the three Miller guidelines. The third requirement that "whether the work, taken as a whole, lacks serious literary, artistic, political, or scientific value" is a possible mitigating factor. Although the reasoning is close to being circular, any material purchased and placed in a library collection must have "literary, artistic, political, or scientific value" by definition. Otherwise, it would not be considered valuable enough, in the opinion of the librarian, to be added to the collection of the library. For this argument to be influential, the librarian would also have to prove that the purchase was in accordance with the library's policy on collection development and the action of the purchase is justifiable. It would be the task of the librarian and any legal counsel to convince the judge or jury, or even the prosecuting attorney before any charges are filed, of the merits of the work. Although not a civil case, there are elements of discretionary immunity (a librarian using their professional knowledge) in this aspect of criminal law. ${ }^{47}$

Another factor is the fragment found in the Miller guidelines 1 and 3: whether the average person, applying contemporary community standards, would find that the work, taken as a whole, [emphasis added] appeals to the prurient interest, and whether the work, taken as a whole [emphasis added], lacks serious literary, artistic, political, or scientific value. This is not as strict as the belief that a work deemed obscene must be "utterly without redeeming social importance" struck down in Roth, ${ }^{48}$ however, it does offer some protection. The seven manga received by Christopher Handley from Japan should have been considered from cover-to-cover, "taken as a whole" by a judge or jury as a work appealing to prurient interests and lacking serious literary, artistic, political, or scientific value, not focusing on singular artwork on a specific page that was considered obscene. To further complicate the matter, manga are often published both in Japan and other nations, including the United States, as part of a series, and a series can include hundreds of individual comic books. If a single book of a manga with seemingly obscene drawings is the evidence of possible violations of federal or state obscenity laws, then an argument could be made that the Miller test has not been met 
because the entire series, including books not yet published, must be "taken as a whole" and decided on as being obscene or not. "Taken as a whole" further complicates the matter that, unless the manga is translated into English, there are few people, judge or jury members, who are proficient in the Japanese language and also have understanding of Japanese culture to read the entire series and to decide if the work is obscene or not. In the Dwight Whorley case, a defense not taken was to insist that the prosecution prove that the twenty seemingly obscene cartoons were not "stills" from different issues or volumes of a manga series that has literary, artistic, political or scientific value.

A third defense could be found in the definition of possession. State and federal cases concerning the criminality of child pornography depend on creation, dissemination, receiving, and possession. The librarian has no involvement in its creation; only a tangential participation in its dissemination if one interprets making the material available through the circulation policies of the library; receiving is a natural and necessary act in the building of any collection; and possession. However, librarians do not possess the material. Using their expertise and discretion, they use public funds, as opposed to their personal funds, to purchase materials, and after the material is received, the librarian adds it to the library collection, and do not in any way possess the material. In this sense, they are agents of the libraries in its collection development, and the rights of ownership over the materials does not transfers to them, but to the library. ${ }^{49}$

\section{CONCLUSION}

The lack of a clear and concise legal case history of librarians being prosecuted for crimes, especially child pornography crimes, makes this investigation challenging and unfortunately inconclusive. Yet perhaps it is this lack of prosecutions despite the fact that manga are being added to collections at a reasonable rate that should give librarians reassurance that the chances of being prosecuted for collecting and owning Japanese manga are small. Since the passing of the PROTECT Act in 2003, there have been only two cases involving seemingly obscene Japanese cartoons, and neither of these cases involved criminal charges against librarians.

Civil liability immunity of librarians performing their professional collection development duties has rarely been tested in our courts. Criminal liability immunity has never been tested. The best librarians can do is to inform our fellow librarians that we may not have a carte blanche in our collection development duties, and here is a possibility that the librarian has limited criminal liability, especially in sensational and public-attention-grabbing cases such as prosecutions for child pornography. However, there is a greater overriding issue: that even such rare and extreme examples such as prosecution for purchasing virtual child pornography, such as Japanese manga, can add to a librarian's thoughts toward self-censorship. Objections to library purchases can be based on many reasons, including offensive language, sexual contents, unsavory scenes, political prejudices, among others. Librarians are aware that disgruntled citizens have not only made their arguments to remove certain books at local board meetings and in the press, they have attempted to use the powers of the federal court to remove materials they consider inappropriate from public libraries. In 1982, school board members of the Island Trees Union Five School District demanded that books they found offensive in their public libraries be removed. The Supreme Court held that First Amendment Rights did not give school board unlimited rights to remove books it found offensive. In 1995, the Board of Supervisors and the superintendent of Unified School District in Kansas sued in federal court to have the novel Annie on my Mind by Nancy Garden removed from public school libraries. The District Court decided that the book had to be returned to the library because it had educational value. $^{50}$ Jennifer Downey, a librarian involved in collecting LGBT materials for a public library states the various reasons a librarian would perform self-censorship are, "It's hard to find LGBT-themed books," "They don't circulate," "What will it say about me?," "There aren't any (or many) LGBT people in my community," and "I don't have the money in my budget." ${ }^{51}$ Barbara M. Jones, executive director of ALA's Office for Intellectual Freedom, succinctly sums it up well: "There are many reasons for self-censorship, and one is fear." ${ }^{\prime 52}$ Despite the fact that no librarian has been prosecuted for obtaining Japanese manga, this unsettling possibility does add to the fears that can lead librarians to self-censorship.

\section{References}

1. "Man Convicted on Child Porn Charges," Daily Press (Newport News, Virginia, December 2, 2005, C3.

2. United States of America vs. Dwight Edwin Whorley, 550 F.3d 326 (2008).

3. United States of America vs. Christopher S. Handley, 564 F. Supp 2nd 996 (2008).

4. Justin Norrie, "Hardcore Comics Sidestep Porn Law," International News (February 20, 2010): 16.

5. Heidi MacDonald, "How Graphic Novels Became the Hottest Section in the Library," Publishers Weekly 260, no. 18 (May 6, 2013): 20-25; Lorena O'English, J. Gregory Matthews, and Elizabeth Blakesley Lindsay, "Graphic Novels in Academic Libraries: From Maus to Manga and Beyond," Journal of Academic Librarianship 32, no. 2 (March 2006): 173-82.

6. "Pornography," Black's Law Dictionary, 7th ed., edited by Bryan A. Garder, 1181 (Saint Paul, MN: West Group, 1999); Steven H. Gifis, "Pornography," Law Dictionary, 5th ed. (Hauppauge, NY: Barron's Educational Series, 2003): 383.

7. "Obscenity," Black's Law Dictionary, 110; "Obscenity," Law Dictionary, 352.

8. "Congress shall make no law respecting an establishment of religion, or prohibiting the free exercise thereof; or abridging the freedom of speech, or of the press; or the right of the people peaceably to assemble, and to petition the Government for a redress of grievances." First Amendment, Constitution of the United States, 1791

9. "Pornography," West's Encyclopedia of American Law 8 (1997): 113.

10. "Obscenity," West's Encyclopedia of American Law 7 (1997): 368-69. 


\section{FEATURE}

11. The definition of "obscene" in The Webster's Third International Dictionary of the English Language Unabridged, edited by Philip Babcock Gove, 1557 (Springfield, MA: G. \& C. Merrian Company, 1968), is "disgusting to the senses usually because of some filthy, grotesque, or unnatural quality" and "offense or revolting as countering or violating some ideal or principle." From this definition, "obscenity" does not necessarily include the pornographic.

12. Comstock Act, 17 Stat. 598 (1873).

13. Regina vs. Hicklin, Law Reporter 2 Queen's Bench 260 (1868); Obscene Publication Act, 20 \& 21 Victoria c. 83 (1857).

14. Katherine Mullin, "Poison More Deadly than Prussic Acid: Defining Obscenity after the 1857 Obscene Publications Act (1850-1885)" in Prudes on the Prowl: Fiction and Obscenity in England, 1850 to the Present Day, edited by David Bradshaw and Rachel Potter, 11-30 (Oxford: Oxford University Press, 2013).

15. Rosen vs. United States of America, 161 US 29 (1896).

16. Rosen, 161 US 43.

17. Roth vs. United States of America, 354 US 476 (1957).

18. Roth, 354 US 490.

19. Roth, 354 US 489.

20. Roth, 354 US 484 .

21. Roth, 354 US 486.

22. Jacobellis vs. Ohio, 378 US 194 (1964).

23. Jacobellis, 378 US 185.

24. Jacobellis, 378 US 196.

25. Miller vs. California, 413 US 15 (1973).

26. Miller, 413 US 24.

27. New York vs. Ferber, 458 US 747 (1982).

28. Ferber, 485 US 765.

29. 18 USC $\$ 2256(8)(B)$

30. 18 USC \$2256(8)(D).

31. Ashcroft vs. Free Speech Coalition, 535 US 234 (2002).

32. 18 USC $\$ 1466 A(a)$

33. Ibid

34. 18 USC $\$ 1466 \mathrm{~A}(\mathrm{C})$.

35. Craig Norris, "Manga, Anime, and Visual Art Culture" in The Cambridge Companion to the Modern Japanese Culture, edited by Yoshio Sugimoto, 13 (Cambridge, UK: Cambridge University Press, 2009); Michael Ashkenazi, "Manga," in Encyclopedia of Modern Asia, vol. 4, edited by Karen Christensen and David Levinson, 34 (New York: Charles Scribner's Sons, 2002).

36. Susanna Jones, "Oriental Lolitas," New Statesman 123, no. 4623 (February 3, 2003): 38; Aleardo Zanghellini, "Underage Sex and Romance in Japanese Homoerotic Manga and Anime," Social \& Legal Studies 18, no. 2 (2009): 159-77.
37. Norrie, "Hardcore Comics Sidestep Porn Law," 16.

38. Sharon Kinsella, "Japanese Subculture in the 1990s: Otaku and the Amateur Manga Movement," Journal of Japanese Studies 24, no. 2 (1998): 289-316.

39. Anne Higgonett, "Japanese Art, Contemporary," in Encyclopedia of Children and Childhood: In History and Society, vol. 2, edited by Paula S. Fass, 506 (New York: Macmillan Reference USA, 2004).

40. Ibid.

41. Paul D. Healey, Professional Liability Issues for Librarians and Information Professionals (New York: Neal-Schuman, 2008), 28.

42. "Public Officers and Employees § 9," 63C American Jurisprudence 2nd (Saint Paul, MN: Thomson/West, 2006). Note on the definition of "public officer or public official." The laws concerning civil liability covers "public officers and public officials," however, there is nothing in the literature that explicitly states that civil liability immunity can be extended to librarians employed in the private sector, such as private colleges and universities or small libraries located in business and corporations. One of the limitations of this paper is the assumption that civil liability immunity can be granted to "private" librarians.

43. Kimps vs. Hill, 187 Wis.2d 508 (1994).

44. Arnold Via vs. City of Richmond, 543 F.Supp. 382 (1982).

45. John Cannan, "Are Public Law Librarians Immune from Suits? Muddying the Already Murky Waters of Law Librarians Liability," Law Library Journal 99, no. 1 (2007): 14.

46. Paul D. Healey, "Chicken Little at the Reference Desk: The Myth of Librarian Liability," Law Library Journal 87, no. 3 (1995): 532.

47. Cannan, "Are Public Law Librarians Immune from Suits?," 14.

48. Roth, 354 US 484.

49. "Classification of Property: A. Public vs. Private" §\$17, "Ownership" \$\$39-48, "Evidence and Proof of Ownership, Title, or Possession” §§67-71, Corpus Juris Secundum, vol. 73 (Saint Paul, MN: Thomson/West, 2004).

50. Debra Lau Whelan, "A Dirty Little Secret: Self-Censorship is Rampant and Lethal," School Library Journal 55, no. 2 (February 2009): 30. See also Board of Education v Pico 457 US 853 (1982) and Case v. United School District No. 233 (D. Kan. 1995) 908 F. Supp. 864.

51. Jennifer Downey, "Self-Censorship Selection of LGBT-Themed Materials," Reference \& User Services Quarterly 53, no. 2 (Winter 2013): 105-6.

52. Barbara J. Jones, "Controversy in Fifty Shades of Gray," American Libraries 43, no. 5/6 (May/June 2012): 21. 